\title{
Regional ethnic autonomy: thinking and actions on the reconstruction of a unified multi-ethnic country by the CPC
}

\author{
Jianyue Chen $i$
}

Received: 6 May 2020 / Accepted: 16 June 2020 / Published online: 04 July 2020

(C) The Author(s). 2020 Open Access This article is licensed under a Creative Commons Attribution 4.0 International License, which permits use, sharing, adaptation, distribution and reproduction in any medium or format, as long as you give appropriate credit to the original author(s) and the source, provide a link to the Creative Commons licence, and indicate if changes were made. The images or other third party material in this article are included in the article's Creative Commons licence, unless indicated otherwise in a credit line to the material. If material is not included in the article's Creative Commons licence and your intended use is not permitted by statutory regulation or exceeds the permitted use, you will need to obtain permission directly from the copyright holder. To view a copy of this licence, visit http://creativecommons.org/licenses/by/4.0/.

\begin{abstract}
The founding of the People's Republic of China (PRC) established and consolidated a new type of socialist ethnic relations, and the people of all ethnic groups in China have embarked on a socialist road since then. This "had never occurred in thousands of years" in the history of China's ethnic relations and was based on the correct path for solving ethnic issues with Chinese characteristics pioneered by the Communist Party of China (CPC), the institutional core of which is the system of regional ethnic autonomy. So to speak, the system of regional ethnic autonomy, as a fundamental political system of the country, is the reconstruction of the important content and system of ethnic relations and the reconstruction of the governance system of a unified multi-ethnic country. Around the year of 1949, the Chinese communists planned the system of regional ethnic autonomy in a systematical and comprehensive manner, and established a basic discourse guiding the ethnic work, ethnic policies and ethnic studies in the PRC. On the basis of historical literature, this paper arranges and sorts out the ethic policies and thinking context at the early stage of the governance by the CPC.
\end{abstract}

\section{J. Chen}

Research Office of Ethnic Theory, The Institute of Ethnology and Anthropology, The Chinese Academy of Social Sciences, Beijing, China

\section{J. Chen $(\bowtie)$}

National Governance Think Tank of the Chinese Academy of Social Sciences, Beijing, China e-mail: jychen@cass.org.cn 
Keywords Regional ethnic autonomy $\cdot$ Ethnic issues $\cdot$ Chinese nation

\section{Introduction}

In any unified multi-ethnic country, ethnic issues are part of the overall social problems; the unity among ethnic groups and the harmony of ethnic relations are not only related to the unity and stability of multi-ethnic countries, but also related to social development and harmony. Looking back at the past 70 years in 2019, the 70th anniversary of the founding of the PRC, it can be found that the reason why this unified multi-ethnic country can develop continuously, and its stability is closely related to the original intention, planning and design of the founders of New China.

China is a unified multi-ethnic country. General Secretary Xi Jinping pointed out at the Central Working Conference about Ethnic Affairs held in 2014 that New China regards ethnic equality as one of the fundamental principles for the foundation of the nation; all ethnic groups are masters of the country; any ethnic oppression and discrimination should be opposed; the new socialist ethnic relations should be established and consolidated; and the people of all ethnic groups should be guided to take the socialist road. This "had never occurred in thousands of years" in the history of China's ethnic relations and was based on the correct path for solving ethnic issues with Chinese characteristics pioneered by the CPC, the institutional core of which is the system of regional ethnic autonomy. So to speak, the system of regional ethnic autonomy, as a fundamental political system of the country, is the reconstruction of the important content and system of ethnic relations and the reconstruction of the governance system of a unified multi-ethnic country.

\section{Discussion}

Using the concept of "Chinese nation" to "unify all ethnic groups into one"

The Long March of the Red Army is a practical journey for the CPC to deeply understand the national conditions that China is a multi-ethnic country. At the Shawo (in Sichuan province) Meeting held in August 1935, the Political Bureau of the CPC Central Committee specifically arranged a section on "Basic Guidelines for the Party on Ethnic Minorities" in the Resolution of the Meeting, which pointed out that "the future activities of the Red Army in northwestern China cannot be separated from the participation of ethnic minorities, therefore striving for ethnic minorities' acceptance of the leadership of the CPC and the Chinese Soviet Government will have a decisive significance for the victory of the Chinese Revolution", and expressly stated that "theories and methods of Marx, Lenin and Stalin on ethnic issues are our most reliable weapons to solve issues on ethnic minorities. Only based on such theories and methods, can we have clear principles and guidelines in our work. Learning from Marx, Lenin and Stalin on their theories 
and methods of ethnic issues is an urgent task for our entire Party." (Resolution of the Central Committee on the Political Situation and Tasks after the Confluence of the 1st and 4th Military Forces 1935).

The understanding of such national conditions also provided support for the CPC's policy adjustments when the "current political situation changed". "The current political situation had undergone a fundamental change and a new period emerged in the history of the Chinese Revolution." "After devouring the four provinces of Northeast China, Japanese imperialists have now invaded the whole North China, and are preparing to take over the whole China, transforming China from a semi-colony occupied by many imperialist powers into a colony by Japanese alone. This is the most basic feature of the current political situation." According to the change, the Political Bureau of the CPC Central Committee called for "a sacred national war against Japanese imperialism and its jackals, and the traitors to China" at the Wayaobao (in Shaanxi province) Meeting. At the same time, the CPC Central Committee explicitly restructured the governing body established during the Chinese Soviet period from "workers and peasants" to "the people". "In order to obtain a broader and stronger foundation for the National United Front, the Chinese Soviet Republic of Workers and Peasants and its Central Government declared: change the country into the Chinese Soviet People's Republic, and change the policies, namely, policies of the Soviet Republic, into those more suitable for the opposition to Japanese imperialism. These policy changes, first of all, fully indicate that the Soviet itself represents not only workers and peasants but also the Chinese nation. The basic interests of the Chinese nation lie in China's freedom, independence and unity, which could only be obtained and maintained under the resolute principles of the Soviet, and could completely oppose the enemies of such interest-imperialism and traitors."(The Central Committee's Tasks on the Current Political Situation and the Party 1935) 2 days later, in a message conveying the decision of the Meeting, the CPC Central Committee used the concepts of "the entire Chinese nation" and "the Chinese nation" to state that, "In this situation, the Party's strategic guidelines are to develop, unify and organize all the revolutionary forces of the Chinese nation and to oppose the current enemies", and reaffirmed that the change in the subject of the Soviet government was "to get ready to fight directly against Japanese and fight for the independence and liberation of the Chinese nation." (Summary of the Current Situation and the Resolution of the Party's Strategic Routes from the Central Committee to the 26th Army Corps 1935)) In May 1936, when the Long March came to an end, the Chinese Soviet made explicit reference to the "five Chinese ethnic groups" in the Declaration to the Hui People, which indicated that the CPC Central Committee had a "multi-ethnic" idea about the internal structure of the concepts of "China's nation," "Chinese nation" and "the entire Chinese nation". "The people and the land of our five Chinese ethnic groups have been slaughtered and invaded by Japanese imperialism." (Declaration of the Chinese soviet central government on the Hui people 1936).

After the Xi' an Incident, in the Ten Guidelines for Resisting Against Japaneses and Salvaging Country published in 1937, the CPC further called for "a general mobilization of the national people" and a "national unity, for the War of 
Resistance against Japanese Aggression" , "mobilizing the Mongolian, the Hui and all other ethnic minorities to jointly resist Japan under the principles of ethnic selfdetermination and ethnic autonomy" and "establishing an a national united front against Japanese aggression for all parties, factions, walks of life and armies, to lead the war of resistance, and to unite together with all the faith and dedication, and to overcome the national crisis". (Ten Outlines of the Communist Party of China for Resisting Japan and Saving the Nation 1937) In July of the same year, the CPC Central Committee decided to set up a working committee for ethnic minorities, with Gao Gang serving as the secretary.

At the 6th Plenary Session of the 6th CPC Central Committee held in October 1938, Mao Tse-tung further elaborated the policy for uniting all ethnic groups in the War of Resistance in his political report on behalf of the CPC Central Committee, and expressly advocated "unifying all ethnic groups into one", he said, "our national united front against Japanese aggression is not only composed of various parties and classes in the country, but also of various ethnic groups. Facing the enemy's ongoing and future trickery to split Chinese ethnic minorities, the 13th Task at present is to unite all ethnic groups into one to combat the Japanese invaders." (Mao 1938) Zhang Wentian also stated that "the CPC Central Committee should organize an ethnic minority committee to pay special attention to the work for ethnic minorities, study and summarize experiences, and train and unite the cadres of ethnic minorities." (Luo and Wentian 1938) "Based on the preliminary experience of the Dingbian(in Shaanxi province) Working Committee for the Mongolian and Hui peoples, Li Weihan raised questions of several policy boundaries to be paid attention to and handled in the work for these two ethnic groups respectively." (Li 1986) In the Political Resolutions of the 6th Plenary Session of the 6th CPC Central Committee, the CPC Central Committee clearly identified the Chinese nation as "national-ethnic" two-tier structure and called for "unified efforts of all Chinese ethnic groups (such as Han, Manchu, Mongolian, Hui, Tibetan, Miao, Yao, Yi and Fan peoples) to jointly resist the Japanese invaders for survival."(Political Resolution of the Enlarged 6th Plenary Session of the Communist Party of China 1938).

"Building a new society and a new country for the Chinese nation"

In early 1939, the CPC Central Committee decided to set up the Northwest Working Committee "to preside over the work of the local underground CPC in provinces of Shaanxi, Gansu, Ningxia, Qinghai, Xinjiang and Mongolia in the Northwest China except the Shaanxi-Gansu-Ningxia Border Region, especially the work for ethnic minorities," with Zhang Wentian, then director of the Publicity Department of the CPC Central Committee, serving as the director and Li Weihan as the secretary-general. At the end of 1939, Mao Tse-tung pointed out in the special section of "The Chinese Nation" in the article Chinese Revolution and the Communist Party of China that in addition to the Han nationality, the Chinese nation "also has Mongolian, Hui, Tibetan, Uighur, Miao, Yi, Zhuang, Zhongjia and Korean ethnic groups, among dozens of other ethnic minorities. Although their cultural development differs, they all have a long history," and "China is a country 
with a large population formed by a combination of multi-ethnic groups." (Mao 1939).

In January 1940, Mao Tse-tung published Politics of New-democracy and Culture of New-democracy at the 1st Congress of the Cultural Association of the Shaanxi-Gansu-Ningxia Border Region. In this important article renamed On the Theory of New-democracy, Mao Tse-tung proposed that the aim of the Chinese communists was to "build a new society and a new country of the Chinese nation", he even proposed to regard "the people's congress" as the country's authority, and "China can now adopt the system of national people's congress, provincial people's congress, county-level people's congress, district people's congress and township people's congress, and governments should be elected at the people's congresses at all levels." (Mao 1940) In February, Jia Tuofu explained in an article the relationship between each ethnic group and the Chinese nation and their status in the Chinese ethnic relations. "The Chinese nation is composed of Han, Manchu, Mongolian, Hui, Tibetan, Uyghur, Miao, Yao, Yi and Fan ethnicities. Therefore, China's complete victory in the War of Resistance against Japanese invaders will have no final guarantees without the active participation by various ethnic groups in the country. The whole China is an oppressed nation in terms of imperialism, but there is also the phenomenon of mutual oppression in the relations among various ethnic groups in the country, with the oppression of Han chauvinism more frequent. These oppressions resulted in constantly brutal fights among ethnic groups in Chinese history. Without overthrowing the oppression and aggression of imperialism, first of all, Japanese imperialism against China, the final liberation of the Chinese nation is impossible. In this regard, the fates of all ethnic groups in the country are completely the same. But at the same time, it will also be impossible to mobilize the strength of the entire Chinese nation to overcome the oppression of Japanese imperialists and all other imperialists if the oppression of Han chauvinism is not eliminated and issues on ethnic groups in China are not correctly solved." (Guan and Tuofu 1940).

In April 1940, Jia Tuofu drafted the Outline for Issues concerning the Hui Ethnicity on behalf of the "Northwest China Working Committee". ${ }^{1}$ In this outline which was later approved by the Central Secretariat and became the instruction of the Party on issues concerning the Hui ethnicity, "three basic conditions" of the Hui and "three historical tasks" for the resolution were summed up. "Facing with the Hui, there are three basic contradictions: the contradiction between the Hui and the Japanese invaders, the ethnic contradiction between the Hui and the Han and the class contradiction between internal democratic forces of the Hui (mainly peasants) and feudal residual forces. Therefore, the historical tasks for the solution are to overthrow Japanese imperialism, eliminate internal ethnic inequality and feudal remnants. But the solution is inseparable from the development and victory of the entire Chinese Revolution." (Li Weihan, 2014).

\footnotetext{
${ }^{1}$ Li Weihan: "Reminiscing the Ethnic Work in Yan'an - Commemorating Comrade Jia Tuofu", Ethnic Studies(民族研究), 1981 (1). “The Outline for Issues concerning the Hui Ethnic Group” was reported to the Central Committee in June 1939, indicated by Mao Tse-tung "which was adopted by the Central Secretariat in principle", and then sent to Party committees at all levels in April 1940, Zhou Weiren(周 维仁): Biography of Jia Tuofu(贾拓夫传), Beijing: Unity Press(团结出版社), 2009, P59-60.
} 
In the book The destiny of China published in 1943, Chiang Kai-shek proposed that "the Chinese Nation is a single minzu (ethnicity)",while each ethnic group in China "is one of the clans of the Chinese Nation". "Chiang's elaboration of this model involved a redefinition of the word minzu to mean the nation as a whole, rather than individual ethnicities." (Knorr 2016) Out of completely different cognitions from Chian Kai-shek's, Mao Tse-tung not only amendmented and arranged for extensive promotion of disproving articles by Chen Boda et al., but also pointed out in the Political Report of the 7th National Congress of the CPC that "the Kuomingtang anti-people's group denies the existence of multi-ethnic groups in China and calls ethnic minorities other than the Han's 'clans'. They have fully inherited the reactionary policies of the Qing government and Northern Warlords, they oppress and exploit all the ethnic minorities in all respects." Therefore, on behalf of the CPC, Mao Tse-tung oppositely proposed "to lead the people of the country after liberation, and to build China into a new country of independence, freedom, democracy, unity and prosperity". In its specific outline, Mao Tse-tung considered "it appropriate and minimal to improve the status of domestic ethnic minorities, and grant them the right to ethnic autonomy". "We must help the broad masses of all ethnic minorities, including all leaders who are connected to the masses, to strive for their political, economic and cultural liberation and development, and to organize armies of ethnic minorities that should safeguard the interests of the masses. Their languages, characters, customs, habits and religious beliefs should be respected." (Mao 1945).

After the victory of the the War of Resistance against Japanese Aggression in 1945, the CPC Central Committee instructed "to organize local Mongolian autonomous government in Mongolian area in Suiyuan where Mongolians inhabit." (Directive of the central Committee of the Communist Party of China on organizing local Mongolian autonomous government and Army for comrade He Long and Lin Feng 1945) Ulanhu was appointed to return to Inner Mongolia to start the organization work. In October of the same year, the CPC Central Committee clearly stated in its instructions on work for Inner Mongolia, "At present, the basic policy for Inner Mongolia is to implement regional autonomy." (Directive of the Central Committee of the Communist Party of China on the Work Guidelines for Inner Mongolia to the Shanxi-Chahar-Hebei(晋察冀) Central Bureau 1945) In November 1946, the CPC Central Committee required "to avoid taking the form of an independent state"concerning the establishment of the Inner Mongolia autonomous government (Directive of the central Committee of the Communist Party of China on considering the establishment of the Inner Mongolian Autonomous Government 1946). On the eve of the establishment, the CPC Central Committee specifically stated, "The relation between the Inner Mongolia autonomous government and China should be confirmed in the Declaration of the Meeting that the Inner Mongolia autonomous government is not an independent government. It recognizes that the Inner Mongolia Autonomous Region still belongs to the territory of China and is willing to be part of China's true democratic coalition government. What it opposes is the dictatorship of the Chiang Kai-shek Kuomingtang government and its designated pseudo-constitution that deprives the right of ethnic autonomy and its traitorous and reactionary policy 
that supports the Civil War." (Directive of the Central Committee of the Communist Party of China on Inner Mongolian Autonomy 1947) The preparation and establishment of the Inner Mongolia Autonomous Region manifested that the CPC had regarded regional ethnic autonomy as the preferred policy for dealing with domestic ethnic issues.

Although the Inner Mongolia Autonomous Region had been established, the CPC leaders did not fully resolve to implement the system of regional ethnic autonomy throughout the country even in 1948. In September 1948, Mao Tse-tung raised the issues concerning the "Central Government" in the Agenda of the Meeting of the Political Bureau of the CPC Central Committee, and proposed that "a state of the people's democratic dictatorship is represented by the government generated by the people's congress". He also proposed that at the stage of newdemocracy, "there are internal ethnic contradictions, such as those between the Han and ethnic minorities in Tibet, Xinjiang and other places, the contradiction between the Han and the Hui, and the contradiction within a certain ethnic group. These can be solved by the Soviet methods." (Mao 1948).

"Ethnic policies are aimed at regional autonomy"

With the development of China's War of Liberation, the establishment of a new unified multi-ethnic country became the core issue to be considered by the CPC. The Political Bureau of the CPC Central Committee stipulated the following tasks for the year of 1949: convene the 2nd Central Plenary Session of the 7th CPC Central Committee after the liberation of Peking; consider "adopting a draft common program to be submitted to the Chinese People's Political Consultative Conference" and "adopting a draft concerning the main components of the Central Government" and other matters related to the founding of New China. (The Current Situation and the Party's Tasks in 1949 1949) After the end of the Pingjin (Peking and Tianjin) Campaign, the CPC Central Committee not only proposed the slogan "Long Live the People's Democratic Republic of China", but also the slogan "Long Live the Chinese Nation's Liberation", which indicated the CPC's juxtaposition plan for the construction of the state and the nation in a synchronized way. In addition, the CPC repeatedly reminded local Party organizations to pay special attention to ethnic affairs under the Chinese nation framework and discuss ways and methods for handling such affairs. ${ }^{2}$

From the end of January to early February 1949, the leader of the Communist Party of the Soviet Union (CPSU) Mikoyan visited Xibaipo (in Hebei province) secretly. On behalf of the CPSU Central Committee, he had conversations and discussions with the CPC leaders such as Mao Tse-tung, Liu Shaoqi, Zhou Enlai,

\footnotetext{
${ }^{2}$ For example, the CPC Central Committee, in its directives to the municipal committees of Peking and Tianjin and the North China Bureau, proposed that "In the future, Mongolian and Tibetan schools will be converted into ethnic colleges to train revolutionary cadres of ethnic minorities. Please consider which is more appropriate, establishing such schools separately or putting them under other schools?" "Central Directives on Several Policy Issues to Peking Universities" (March 17, 1949), Selected Documents of the Central Committee of the Communist Party of China(中共中央文件选集), Volume 18 , P176.
} 
Zhu De and Ren Bishi. During the one-week talks, the CPC leaders basically made up their mind to deal with ethnic issues through the system of regional ethnic autonomy. In the talks, Mikoyan did not recommend the CPC to adopt federalism to deal with ethnic issues, that is, "autonomy should be granted to ethnic minorities, but not independence". "Mao Tse-tung was pleased with the proposal. It could tell from his countenance that no matter which ethnic group it was, he did not intend to make it independent." (Minutes of the Talks between Mikoyan and Mao Tse-tung: Issues on Ethnicity and Foreign Relations 1949) In the memoir of witnesses on the part of the CPC, Mao Tse-tung told Mikoyan:

China is a multi-ethnic country with dozens of ethnic groups, among which the Han has the largest population. Most of other ethnic groups, such as Mongolian, Hui, Tibetan and Uygur ethnicities, live in remote areas. Compared to Han ethnicity, they are all ethnic minorities. It is customary to call the Han people Chinese, but the Chinese do not only refer to the Han people. All the ethnic groups living in the territory of China are Chinese ... The ethnic policies are mainly against Han chauvinism. This is currently the case. But historically, Han ethnicity has also been enslaved and ruled by other ethnicities many times, though it is a large ethnic group. In short, ethnic policies must be correct; ethnic oppression must be banned; and disputes among ethnic groups must be properly settled. We advocate unity, mutual assistance, friendship and cooperation among ethnic groups to build the country together. It is inevitable that certain frictions or disputes among ethnic groups, or even contradictions or conflicts occurred, but can be settled easily today. At present, the main task is to prevent and oppose Han chauvinism, and at the same time oppose local nationalism. Both are the root causes of hindering and destroying national unity and common development. Our army is moving forward and will soon enter areas where ethnic minorities inhabit. Therefore, a set of corresponding guidelines and policies on ethnic issues will be formulated in the near future. (Shi and Shi 2001)

The declassified archives of the Soviet Union and the memoir of the Chinese side can not only testify each other, but also fully confirm that the implementation of policies and systems different from the Soviet federalism in New China was a consensus reached between the CPC and the CPSU based on different national conditions.

It was also during this period that Mao Tse-tung sought Li Weihan's opinion on whether or not to implement federalism. Li Weihan, who had been studying ethnic issues for a long time, believed that China and the Soviet Union had different national conditions and it was not appropriate to implement federalism. "Will China follow the path of national republic and federalism or the path of regional ethnic autonomy to solve ethnic issues? This is a major issue facing the CPC and the country on the eve of the founding of New China. During the preparation for the CPPCC, Chairman Mao consulted with Comrade Li Weihan on this issue... Comrade Li Weihan proposed the implementation of regional ethnic autonomy in a unified (unitary) country. Chairman Mao and the CPC Central Committee agreed 
to this proposal and made clear provisions in the Common Program." (Huang 1996) Meanwhile, the CPC leaders also paid special attention to understanding the situation in ethnic regions and listening to demands of ethnic minorities. Zhou Enlai asked Deng Liqun, then secretary general of the Xinjiang Sub-bureau of the Central Committee of the Communist Party of China, to convey his remarks to the Xinjiang representatives who participated in the new CPPCC, "Please prepare for materials on Xinjiang's political, military, economic, cultural, Party affairs, and first of all, ethnic affairs," and "please don't prepare gifts for our CPC leaders other than the opinions and requirements put forward by the Xinjiang people, which are the best gifts." (Zhou 1949).

Ethnic policy planning with regional ethnic autonomy as the core continued to be manifested in the "national-ethnic" two-tier structure within a unified multi-ethnic country. Ethnic minorities were treated as part of the Chinese nation in terms of systems, laws and policies. Within the Chinese nation framework, the institutional arrangements and rights guarantees for regional ethnic autonomy would be granted. In Zhou Enlai's Initial Draft of the Common Program for Newdemocracy, the new-democratic state system of New China was identified as "the state system of people's democratic dictatorship under the leadership of the working class based on the workers-peasants alliance that unites all democratic classes and all ethnic groups within the territory of China," because "only this system can achieve the equal union of all ethnic groups in China, so that all ethnic groups enjoy equal status in the state power and fulfill the right to the autonomy of all ethnic groups." It is worth noting that although in the "General Outline" it was mentioned that "ethnic minorities can form a federation of all Chinese ethnic groups in accordance with the principles of voluntariness and democracy", which was literally similar to federalism, the "federation of all Chinese ethnic groups" of the CPC actually referred to regional ethnic autonomy under a unitary system, which could be found in the "Specific Outline" below, "All ethnic groups in China are equal. All ethnic minorities have the right to establish different levels of selfgovernment- autonomous regions, prefectures and counties or banners and to implement democratic alliances. All ethnic minorities have the right to use their own languages and characters, and to preserve their religious beliefs and living habits. Inter-oppressions, first of all, the oppression of Han ethnicity against other ethnic minorities shall be eradicated, and propaganda of ethnic hatred and contempt for ethnic minorities shall be opposed." (Zhou 1949a) At the meeting of new CPPCC, Zhou Enlai, on behalf of the CPC, explained to the CPPCC representatives:

Regarding the state system, there is another question: does our country adopt a multi-ethnic federalism? Now we can put forward the ideas for consideration when we drafted the system. China is a multi-ethnic country, with the characteristics that Han ethnicity has a population of over 400 million, accounting for the largest part of the population. Ethnic minorities including the Mongolian, Hui, Tibetan, Uyghur, Miao, Yi and Gaoshan ethnic groups, among others, accounts for less than ten percent of the national population. Of course, regardless of the number of people, all ethnic groups are equal. First 
of all, Han ethnicity should respect the religions, languages, customs and habits of other ethnic groups. The main issue here is whether ethnic policies are aimed at autonomy or exceed it. We advocate ethnic autonomy, but we must prevent imperialism from using ethnic issues to provoke dissensions on the unification of China.

The Qing Dynasty's policy of oppressing ethnic minorities was to deceive and massacre ethnic groups other than the Manchu ethnicity. The Northern Warlords Government continued adopting the policy of ethnic oppression, and the Kuomintang reactionary government deepened it. We should change it by uniting all ethnic groups into one big family, and preventing the provocation and division by imperialism ... To this end, the name of our country is called the People's Republic of China, not the Federation; many people who attend the meeting today are ethnic representatives. We make a specific explanation here today, and we also hope that everyone will agree with it. Although we are not a federation, we advocate regional ethnic autonomy and exercise the power of ethnic autonomy. (Zhou 1949b)

In the Common Program with the function of an interim constitution, Article 50 expressly provides, "All ethnic groups in the territory of the PRC shall be equal, and shall be united to help each other and fight against imperialism and their internal public enemies, to make the PRC a big fraternal and cooperative family for all ethnic groups. Both chauvinism and local nationalism shall be opposed and any acts involving ethnic discrimination and oppression, as well as splitting of the national solidarity shall be prohibited." (Common Program of the Chinese People's Political Consultative Conference 1949) Zhou Enlai explained in the Common Program concerning "ethnic policies of new-democracy" that "the basic consideration is to make the PRC a big fraternal and cooperative family for all ethnic groups, and fight against their internal public enemies and external imperialism. In this big family, tendencies for both chauvinism and local nationalism must be opposed. The regional autonomy of all ethnic minorities, the right for organizing armed forces and the respect for their religious beliefs should be expressly stipulated in the provisions." (Zhou 1949c).

In the view of the CPC leaders, handling ethnic issues under the guidance of the basic principles of the Marxist ethnic theory and in combination with the national conditions with multi-ethnic groups was an important component of the application of the Marxist ethnic theory in China. "Chairman Mao's theory is to sinicize Marxism-Leninism, giving play to those principles suitable for China. This is the combination of theory and practice." Starting from this, Zhou Enlai made preliminary provisions on the elements of the system of regional ethnic autonomy, "Each ethnic minority has the right to autonomy, and governs itself under unified decrees," and emphasized that the main content of the ethnic policies of the CPC and the country was "regional ethnic autonomy", and "The implementation of regional ethnic autonomy has no disadvantages but advantages.. Today unity is the common desire of our big family. 
The only correct way is to implement regional ethnic autonomy." (Zhou 1950) Zhou Enlai's remarks may be the initial form of the expression "the correct path for solving ethnic issues with Chinese characteristics."

By the end of 1951, the system of regional ethnic autonomy had been fully implemented in ethnic regions. "For example, in the Northwest China, 8 autonomous administrative divisions have been established; in the southwest, 85 regional ethnic autonomies and 163 national democratic coalition governments(民族民主联合政府) have been established; in the south-central region, 6 regional ethnic autonomies and 2 National Democratic Coalition Governments have been established. Throughout the country, 113 regional ethnic autonomies and 165 National Democratic Coalition Governments were established within two years. The larger ones areequivalent to prefectures and the smaller ones counties, districts and townships." (Liu 1958) Under this background, the 2nd Enlarged Meeting of Members of the Central Ethnic Affairs Committee was held in Beijing. This meeting was considered to be "of the nature of a national conference of ethnic representatives." (Ulanhu 1952a, 1952b) At this meeting where the Draft Outline for the Implementation of Regional Ethnic Autonomy was put forward, Li Weihan, head of the United Front Work Department of CPC Central Committee, reiterated the basic discourse on ethnic issues in China, and gave a full definition of the regional ethnic autonomy for the first time, "Regional autonomy of ethnic minorities is based on regions where ethnic minorities inhabit within the territory of the PRC, which follows the general path under the Common Program of the Chinese People's Political Consultative Conference, and also under the unified leadership of the Central People's Government." "In accordance with this general principle and major premise, all ethnic minorities gathering in a community have the right to implement regional autonomy, establish regional autonomies and organs, and manage their internal affairs according to the wishes of the majority of their people and the leaders associated with their people." (Li 1951) In this report, (Li Weihan, on behalf of the CPC Central Committee, made normative plans for the administrative levels of autonomous areas, the population requirement for establishing autonomous areas, the legislative authority of autonomous organs and the leadership of the superior governments.

By June 1952, the number of regions implementing regional ethnic autonomy had reached 130, and ethnic minorities implementing regional ethnic autonomy had a population of 4.5 million. (Strengthening Regional Ethnic Autonomy 1952) Therefore, when the central government reviewed the Outline for the Implementation of Regional Ethnic Autonomy on August 8, 1952, Ulanhu pointed out that "the full and correct exercise of these autonomous rights can give full play to the enthusiasm and initiative of autonomous regions and strengthen ethnic unity, so as to achieve full progress of the ethnic groups practising regional autonomy." (Ulanhu 1952a, 1952b).

On June 15, 1953, Mao Tse-tung proposed the "change from new-democracy to socialism" at the Meeting of the Political Bureau of the CPC Central Committee.(Mao 1953) The 3rd National United Front Work Conference held in the same year stipulated on behalf of the Central Committee that the CPC's tasks in ethnic issues 
were to "consolidate the unification of the motherland and the unity of all ethnic groups and jointly build a big family of the great motherland; guarantee the equality of all ethnic groups in all rights; and implement regional ethnic autonomy; in the common development of the motherland, while working in line with the construction of the motherland, gradually develop the politics, economy and culture of all ethnic groups (including steady and necessary social reforms), and eliminate the de facto inequality among ethnic groups inheriting from history, so that the left-behind ethnic groups can join the ranks of well-developed ones and transit to the socialist society." 3 This means that the initial phase of the founding of the PRC was basically over, and the socialist multi-ethnic China hereby set sail.

\section{Conclusion}

Regional ethnic autonomy is an ethnic affairs management system developed in accordance with the basic principles of Marxist ethnic theory and in combination with China's conditions. Zhou Enlai pointed out in 1957 that "since the adoption of the Common Program, we have adopted the policies for regional ethnic autonomy based on the general principles of Marxism-Leninism on ethnic issues and the actual situations of ethnic relations in China. We do not advocate ethnic separation and do not adopt federalism." In his view, "If China adopts federalism, boundary walls among all ethnic groups and ethnic disputes will increase, because many ethnic minorities in China live in the same areas with the Han ethnicity for a long time. In some regions, such as Inner Mongolia, Guangxi and Yunnan, the Han ethnicity accounts for a large proportion. If strict single-ethnic federalism is implemented, many people will have to move, which will be detrimental to the unity and development of all ethnic groups. Therefore, we did not adopt this approach, but decided to implement the policies for regional ethnic autonomy."

It can be seen that the institutional arrangement for "increasing the boundary walls" in a unified multi-ethnic country is federalism rather than regional ethnic autonomy. "Our policies for regional ethnic autonomy are conducive to cooperation, unity and common development of all ethnic groups." (Zhou 1957) In terms of the idea and original intention of the system creation, the CPC leaders such as Mao Tse-tung and Zhou Enlai had no intention of "increasing boundary walls", on the contrary, they consciously broke the "awareness of boundary walls" among various ethnic groups in history through regional ethnic autonomy. "We advocate uniting all ethnic groups in the country into a big family."(Zhou 1957) This big family composed of all ethnic groups is the community of the Chinese nation, and the system or mechanism that unites all ethnic groups in the community is the

\footnotetext{
3"Summary of the Party's Major Experience in Working with Ethnic Minorities in the Past Several Years" at the National United Front Work Conference of the Central Committee of the Communist Party of China (October 24, 1954), Selected Important Documents since the Founding of the PRC(建国 以来重要文献选编), Volume 5, P650. Others believe that Mao Tse-tung said this at the meeting of the Political Bureau, see Shi Nongxin, Yang Shaoquan (石农心、杨绍全):Introduction to Ethnic Issues and Policies(民族问题与民族政策概论)，Chengdu: Chengdu University of Science and Technology Press(成都科技大学出版社), 1987, P64.
} 
system of regional ethnic autonomy under the centralized and unified leadership of the state.

"The People's Republic of China is a unitary multi-ethnic country." "Implementing regional ethnic autonomy is a fundamental policy on ethnic issues after 1949." The so-called unitary entity refers to the belief that multi-ethnic China does not practice federalism. Therefore, the saying of China's copying the Soviet model in ethnic policies, exactly as General Secretary Xi Jinping said, is inconsistent with the facts; why is the regional ethnic autonomy policy regarded as the fundamental policy? As General Secretary Xi pointed out again, it is the source of the CPC's ethnic policies. Both the Party's and the state's ethnic policies come from it and survive on it., therefore it must be consolidated, improved and developed.

General Secretary Xi pointed out at the 4th Central Working Conference about Ethnic Affairs that the correct path for solving ethnic issues with Chinese characteristics is to adhere to the leadership of the CPC, the path of socialism with Chinese characteristics, the maintenance of the unity of the motherland and the equality among all ethnic groups, adhere to and improve the system of regional ethnic autonomy. We should work together for common prosperity and development of all ethnic groups, consolidate the ideological foundation of the community for the Chinese nation and the rule of law, strengthen the communication, exchanges, and integration among all ethnic groups, and promote all our ethnic groups living together in friendship, sharing in a common cause, and developing in harmony, consolidate and develop a socialist ethnic relations featuring equality, solidarity, mutual assistance and harmony, and jointly realize the great rejuvenation of the Chinese nation. General Secretary $\mathrm{Xi}$ also pointed out that the system of regional ethnic autonomy is a basic political system of China, and the main content and institutional guarantee for the correct path to solve ethnic issues with Chinese characteristics.

Practice has proved that the system of regional ethnic autonomy is in line with China's national conditions, and has played an important role in maintaining national unification and territorial integrity, strengthening ethnic equality and unity, promoting the development of ethnic regions and enhancing the cohesion of the Chinese nation. Reviewing our path 70 years after the founding of People's Republic of China, we can understand Xi Jinping's remarks on history more deeply: "Both history and reality tell us that a long historical process is needed for a social revolution to win a final victory. We can see the problems deeply and accurately only by looking back the path we have taken, comparing it with others' and looking ahead to understand where we came from and where we are going." (Jinping 2018).

Acknowledgements Not applicable.

\section{Author's contributions}

The author read and approved the final manuscript. 


\section{Funding}

Not applicable.

\section{Availability of data and materials}

Not applicable.

\section{Ethics approval and consent to participate}

Not applicable.

\section{Consent for publication}

Not applicable.

\section{Competing interests}

Not applicable.

\section{References}

Common Program of the Chinese People's Political Consultative Conference (adopted on September 29, 1949), edited by the Document Research Office of the Central Committee(中央文献研究室编). 1992. Selected Important Documents since the Founding of the PRC (建国以来重要文献选编), volume 1, P12. Beijing: Central Document Press(中央文献出版社).

Declaration of the Chinese soviet central government on the Hui people (May 25, 1936). Selected Documents of the Chinese United Front Against Japanese Aggression of the Central Committee of the Communist Party of China(中共中央抗日民族统一战线文件选编), volume II. 1985, P150. Beijing: Archives Press(档案出版社).

Directive of the central Committee of the Communist Party of China on considering the establishment of the Inner Mongolian Autonomous Government (November 26, 1946), Literature collection on ethnic issues, P1083.

Directive of the Central Committee of the Communist Party of China on Inner Mongolian Autonomy (March 23, 1947), Literature collection on ethnic issues, P1095-P1096.

Directive of the central Committee of the Communist Party of China on organizing local Mongolian autonomous government and Army for comrade He Long and Lin Feng" (September 16, 1945), Literature Collection on Ethnic Issues(民族问题文献选编), P960.

Directive of the Central Committee of the Communist Party of China on the Work Guidelines for Inner Mongolia to the Shanxi-Chahar-Hebei(晋察冀) Central Bureau” (October 23, 1945), Literature collection on ethnic issues, P964.

Guan, Feng (i.e. Jia Tuofu): "Uniting the Chinese ethnic groups for the victory in the war of resistance and the founding of the country" (February 1940), Literature Collection on Ethnic Issues (1921.7-1949.9), P816.

Huang. 1996. Leap in the development of comrade Li Weihan's thoughts and contributions to the theory and practice of Chinese ethnic issues: Commemoration of the centennial anniversary of comrade Li Weihan's 
birth. Ethnic Studies (民族研究) (4) Huang Zhu, Jiang Ping: “A Great Leap in Li Weihan's Thoughts", China United Front(中国统一战线), 1996 (6).

Xi Jinping Delivers an Important Speech at the Opening Ceremony of the Seminar for Studying and Implementing the Spirit of the 19th National Congress of the Communist Party of China, to Lose No Time in Devoting Ourselves to the Creation of a New Pattern of Socialism with Chinese Characteristics for a New Era", People's Daily, January 6, 2018.

Daniel D. Knorr[U.S.] : "Debate on the Destiny of China: Writing the past and future of the Chinese nation during the war of resistance against Japan”, Chief Editors: Zhou Xirui and Li Haotian (周锡瑞、李晧天 主编): China at the Crossroads in 1943(1943: 中国在十字路口), translated by Chen Xiao(陈骁译), Beijing: Social Sciences Literature Press(社会科学文献出版社), 2016, P164.

Li, Weihan. 1986. The northwest working Committee of the Central Committee and the work of ethnic minorities. In Reminiscence and Research (回忆与研究), volume II, ed. Li Weihan, P461-P462. Beijing: CPC Historical Data Press(中共党史资料出版社).

Li, Weihan. 2014. Outline for issues concerning the hui ethnic group. In (April 1940), Li Weihan(李维汉): Issues on the United Front and Ethnic Issues(统一战线问题和民族问题), Beijing: CPC History Press(中共党史出版社), P560.

Li, Weihan: "Several issues on ethnic policies" (December 21, 1951), Compilation of Ethnic Policy Documents(民族政策文件选编), volume 1, Beijing: People's Publishing House (人民出版社), P43.

Liu, Geping. 1958. Ethnic work in the past two years. In (December 20, 1951), Compilation of Ethnic Policy Documents, volume 1, P52.

Luo, Fu (i.e. Zhang Wentian): "Issues concerning party organizations for Chinese united front against Japanese aggression" (October 15, 1938), Selected documents of the central Committee of the Communist Party of China, volume 11, P699.

Mao Tse-tung: "On the new stage" (October 12-14, 1938), edited by the Central Archives: Selected Documents of the Central Committee of the Communist Party of China(中共中央文献选集), volume 11, Beijing: Party School of the Central Committee of C.P.C. Press(中共中央党校出版社), 1991a, P619.

Mao, Tse-tung: "The Chinese revolution and the Communist Party of China" (December 1939), Selected Works of Mao Tse-tung(毛泽东选集), volume 2, Beijing: People's Publishing House, 1991b, P622.

Mao Tse-tung: "On new democracy" (January 1940), Selected Works of Mao Tse-tung, volume 2, P663-P667.

Mao Tse-tung: "On the united government" (April 24, 1945), Selected Works of Mao Zedong, volume 3, Beijing: People's Publishing House, 1991c, P1030-P1084.

Mao Tse-tung: "Report and conclusion at the meeting of the political Bureau of the Central Committee of the Communist Party of China" (September 8 and 13, 1948), edited by the Document Research Office of the Central Committee of the Communist Party of China; Anthology on the Founding of the People's Republic of China(中华人民共和国开国文选), Beijing: Central Document Publishing House(中央文献出版 社), 1999, P12-P23.

Mao, Tse-tung: "Outline of the speech at the meeting of the political bureau" (June 15, 1953), Document research Office of the Central Committee of the Communist Party of China: Mao Tse-tung's Manuscripts since the Founding of the PRC(建国以来毛泽东文稿), volume 4, Beijing: Central Document Publishing House, 1990, P251.

Minutes of the Talks between Mikoyan and Mao Tse-tung: Issues on Ethnicity and Foreign Relations" (February 4, 1949), chief editor: Shen Zhihua(沈志华主编): Selected Russian Declassification Archives: Sino-Soviet Relations(俄罗斯解密档案选编: 中苏关系), volume 1, Shanghai: Oriental Publishing Center(东方出版中心), 2015, P421.

Political Resolution of the Enlarged 6th Plenary Session of the Communist Party of China (November 6, 1938), Selected documents of the central Committee of the Communist Party, volume 11, P752.

Resolution of the Central Committee on the Political Situation and Tasks after the Confluence of the 1st and 4th Military Forces" (August 5, 1935), edited by the Central Archives(中央档案馆编): Selected Documents of the Central Committee of the Communist Party of China, volume 10, Beijing: Party School of the Central Committee of C.P.C. Press, 1991, P534-P536.

Shi, Zhe (oral) and Shi, Qiulang (transcripts): My Life: Read me of Shi Zhe(我的一生:师哲自述), Beijing: People's Publishing House, 2001, P280-P281.

Strengthening Regional Ethnic Autonomy, People's Daily, August 13, 1952.

Summary of the Current Situation and the Resolution of the Party's Strategic Routes from the Central Committee to the 26th Army Corps (December 27, 1935), Selected Documents of the Central Anti-Japanese National United Front of the Central Committee of the Communist Party of China, volume II, P70 and $\mathrm{P} 71-\mathrm{P} 70$ and P72. 
Ten Outlines of the Communist Party of China for Resisting Japan and Saving the Nation" (August 15, 1937), Edited by the united front work Department of the Central Committee of the Communist Party of China(中共中央统战部): Selected Documents on Ethnic Issues(民族问题文献选编)1921.7-1949.9, Beijing: Party School of the Central Committee of C.P.C. Press, 1991, P553-P554.

The Central Committee's Tasks on the Current Political Situation and the Party (December 25, 1935), edited by the Central United Front Work Department of the Communist Party of China and the Central Archives: Selected documents of the Chinese united front against Japanese aggression of the central Committee of the Communist Party of China, P56.

The Current Situation and the Party's Tasks in 1949 (January 8, 1949, Selected documents of the central Committee of the Communist Party of China, volume 18, P22.

Ulanhu: "Report on the Outline for the Implementation of Regional Ethnic Autonomy of the People's Republic of China" (August 8, 1952a), Compilation of ethnic policy documents, volume 1, P74.

Ulanhu: "Report on the outline for the implementation of regional ethnic autonomy of the People's Republic of China" (August 8, 1952b), Compilation of ethnic policy documents, volume 1, P77.

Zhou, Enlai: "Report of the central committee on inviting Xinjiang representatives to participate in the new political consultative conference" (August 1949), edited by the Document Research Office of the Central Committee of the Communist Party of China and the Central Archives: Zhou Enlai's Manuscripts since the Founding of PRC (建国以来周恩来文选), volume 1, Beijing: Central Document Publishing House(中央文献出版社), 2018, P272, P276-P272, P277.

Zhou, Enlai: "Initial draft of the common program for new-democracy" (August 22, 1949a), Zhou Enlai's manuscripts since the founding of PRC, volume 1, P296, P304-P296, P305.

Zhou, Enlai: "Several issues on the People's political consultative conference" (September 7, 1949b), Literature collection on ethnic issues, P1267.

Zhou, Enlai: "Characteristics of the draft common program of the Chinese People's political consultative conference" (September 22, 1949c), Zhou Enlai's manuscripts since the founding of PRC, volume 1, P394.

Zhou, Enlai: "Issues on ethnic policies" (April 27, 1950), Edited by document research Office of the Central Committee of the Communist Party of China, and the Committee of the Tibet Autonomous Region of the Communist Party of China(中央文献研究室、中共西藏自治区委员会编), Selected Documents on Tibetan Work (西藏工作文献选编)(1949-2005), Beijing: Central Document Publishing House, 2005, P15-P16.

Zhou, Enlai: "Regional ethnic autonomy is conducive to National Unity and Common Progress "(March 25, 1957), Edited by the united front work Department of the Central Committee of the Communist Party of China and the central document research office: Selected Works of Zhou Enlai on United Front(周恩来 统一战线文选), Beijing: People's Publishing House, 1984, P339, P342-P339, P343.

\section{Publisher's Note}

Springer Nature remains neutral with regard to jurisdictional claims in published maps and institutional affiliations. 